\title{
Productivity and nutrient use efficiency of hybrid rice (Oryza sativa L.) in response to integrated use of organic and inorganic sources of nutrients
}

\author{
Dinesh Pandey*, Anjum Ahmad, J.K.Chauhan and N. Pandey \\ Department of Agronomy, Indira Gandhi Krishi Vishwa Vidyalaya, Raipur (C.G.) India
}

\begin{abstract}
An experiment was carried out during the Kharif 2002 and 2003, to study the productivity and nutrient use efficiency of hybrid rice (Oryza sativa L.) in response to integrated use of organic and inorganic sources of nutrients at Research farm, IGAU, Raipur (CG). In all 12 treatments, comprising of different $\mathrm{N}, \mathrm{P}$ and $\mathrm{K}$ levels and its conjunction with organic fertilizers were laid out in Randomized Block Design with 3 replications. The results revealed that application of inorganic fertilizer level of 150:80:60 kg NPK ha ${ }^{-1}$ significantly increased number of active leaf, leaf area, leaf area index and dry matter accumulation at later stages as compared to lower level of inorganic fertilizer. The conjunction of 100:60:40 kg NPK ha ${ }^{-1}$ along with PM or N blended with CDU found to be equally effective to that of inorganic fertilizer level of 150:80:60 $\mathrm{kg} \mathrm{NPK} \mathrm{ha}^{-1}$ for above growth parameters. The chlorophyll content during crop period under above level was the highest under said treatment. The highest crop growth rate was observed between 60-90 DAT followed by 90 DAT-harvest and 30-60 DAT, respectively. The per day accumulation of dry matter during 60-90 DAT period was almost three to four times of that accumulated during 30-60 DAT. Thereafter growth rate almost declined till maturity during both the years. The increased concentration of $\mathrm{N}$ at different growth stages and its uptake by plant helped in increasing the yield components and grain yield. The critical analysis of grain yield observations revealed that conjunction of lower levels of inorganic fertilizer (100:60:40 or 50:30:20 kg NPK ha-1) along with CDU or PM gave the saving of 50 $\mathrm{kg} \mathrm{N}, 20 \mathrm{~kg}$ P and $20 \mathrm{~kg} \mathrm{~K} \mathrm{ha}^{-1}$ for the cultivation of hybrid rice. Moreover, the higher buildup of available $\mathrm{N}$ and $\mathrm{K}$ has been also observed under said combination of organic and inorganic fertilizer treatments. The application of 150:80:60 $\mathrm{kg} \mathrm{NPK} \mathrm{ha}^{-1}$ along with PSB gave the highest buildup of available phosphorus. Inorganic level of 150:80:60 $\mathrm{kg} \mathrm{NPK} \mathrm{ha}^{-1}$ gave the highest production efficiency and productivity rating index, which was followed by application of inorganic fertilizer of 100:60:40 $\mathrm{kg} \mathrm{NPK} \mathrm{ha}^{-1}$ along with PM and blending of N with CDU, respectively. The application inorganic fertilizer of 50:30:20 kg NPK ha' + PM gave the highest nutrient efficiency during both the years. The highest input cost, net profit and per rupee investment was found under 150:80:60 kg NPK ha-1 followed by application of 100:60:40 $\mathrm{kg} \mathrm{NPK} \mathrm{ha}^{-1}$ along with PM.
\end{abstract}

Key Words : Nitrogen, Phosphorus, Potassium, Balance sheet, Cholorophyll content, Leaf area index, Active leaf, Nutrients, Hybrid rice

View Point Article : Pandey, Dinesh, Ahmad, Anjum, Chauhan, J.K. and Pandey, N. (2021). Productivity and nutrient use efficiency of hybrid rice (Oryza sativa L.) in response to integrated use of organic and inorganic sources of nutrients. Internat. J. agric. Sci., 17 (2) : 390 403, DOI:10.15740/HAS/IJAS/17.2/390-403. Copyright@2021: Hind Agri-Horticultural Society.

Article History : Received : 25.02.2021; Revised : 27.02.2021; Accepted : 16.03.2021

\footnotetext{
* Author for correspondence :
} 